\title{
A reinvestigation of spermiogenesis in Amphilina foliacea (Platyhelminthes: Amphilinidea)
}

\author{
Magdaléna Bruňanská ${ }^{1}$, Larisa G. Poddubnaya ${ }^{2}$ and Willi E. R. Xylander ${ }^{3}$ \\ ${ }^{1}$ Institute of Parasitology, Slovak Academy of Sciences, Hlinkova 3, 04001 Košice, Slovak Republic; \\ ${ }^{2}$ I.D. Papanin Institute for Biology of Inland Waters, Russian Academy of Sciences, 152742 Borok, Yaroslavl Province, Russia; \\ ${ }^{3}$ Senckenberg Museum für Naturkunde Görlitz, Postfach 300 154, 02806 Görlitz, Germany
}

\begin{abstract}
Spermiogenesis in the amphilinidean cestode Amphilina foliacea (Rudolphi, 1819) was examined using transmission electron microscopy. The orthogonal development of the two flagella is followed by a flagellar rotation and their proximodistal fusion with the median cytoplasmic process. This process is accompanied by extension of both the mitochondrion and nucleus into the median cytoplasmic process. The two pairs of electron-dense attachment zones mark the lines where the proximodistal fusion of the median cytoplasmic process with the two flagella takes place. The intercentriolar body, previously undetermined in $A$. foliacea, is composed of three electron-dense and two electron-lucent plates. Also new for this species is the finding of electron-dense material in the apical region of the differentiation zone at the early stage of spermiogenesis, and the fact that two arching membranes appear at the base of the differentiation zone only when the two flagella rotate towards the median cytoplasmic process. The present data add more evidence for a close relationship between the Amphilinidea and the Eucestoda.
\end{abstract}

Keywords: ultrastructure, testes, spermiogenesis, Amphilina foliacea, Amphilinidea, Cestoda, Platyhelminthes

Ultrastructural data on spermiogenesis and sperm morphology have the potential to contribute significantly to phylogenetic analyses within the Platyhelminthes (Euzet et al. 1981, Świderski 1986, Justine 1998, 2001, 2003, Hoberg et al. 2001, Bruňanská 2010, Levron et al. 2010). In the Amphilinidea, a group possessing unique genes and genomes (Waeschenbach et al. 2012), sperm development has been studied in three species: Amphilina foliacea (Rudolphi, 1819), A. japonica (Goto et Ishii, 1936) and Austramphilina elongata Johnston, 1931 (Bazitov et al. 1979, Rohde and Watson 1986, Xylander 1986, 1993). These observations describe the basic pattern of the developing male gametes; however, a full reconstruction of the process of spermiogenesis has not been attempted within the Amphilinidea. In addition, there are still questions concerning the presence/absence and morphology of the characters, recently considered to be of importance for phylogenetic studies (e.g. the intercentriolar body), in this group of cestodes.

Therefore, the present contribution deals with the process of spermiogenesis in A. foliacea, a parasite of Acipenser stellatus Pallas, in order to complete our knowledge of male gametogenesis and to provide additional data for phylogenetic analyses.

\section{MATERIALS AND METHODS}

Specimens of Amphilina foliacea were obtained from the body cavity of naturally infected specimens of the stellate sturgeon Acipenser stellatus caught in the Caspian Sea basin of the Lower Volga River, Russia. Live worms were fixed in $2.5 \%$ glutaraldehyde in $0.1 \mathrm{M}$ sodium cacodylate buffer at $\mathrm{pH} 7.4$ for 20 days at $5{ }^{\circ} \mathrm{C}$. Small pieces of worms were rinsed in a $0.1 \mathrm{M}$ sodium cacodylate buffer at $\mathrm{pH} 7.4$ and postfixed in cold $\left(5^{\circ} \mathrm{C}\right) 1 \%$ osmium tetroxide in the same buffer for $1 \mathrm{~h}$. The material was dehydrated in a graded series of ethanol and acetone, and embedded in Araldite and Epon. Ultrathin sections ( $70-90 \mathrm{~nm}$ ) were stained with uranyl acetate and lead citrate, and examined in a JEOL-1011 transmission electron microscope operating at $80 \mathrm{kV}$.

\section{RESULTS}

The testes of Amphilina foliacea contain male gametes at various developmental stages, including spermatids. The first sign of ongoing spermiogenesis is the formation of a differentiation zone situated at the periphery of each spermatid (Figs. 1A, 4A). This is a conical protrusion containing two centrioles with rootlets. The centrioles change their orientation and become arranged in the same plane, when the intercentriolar body appears between them (Figs. 1B-D, 4B). This intercentriolar body is com- 

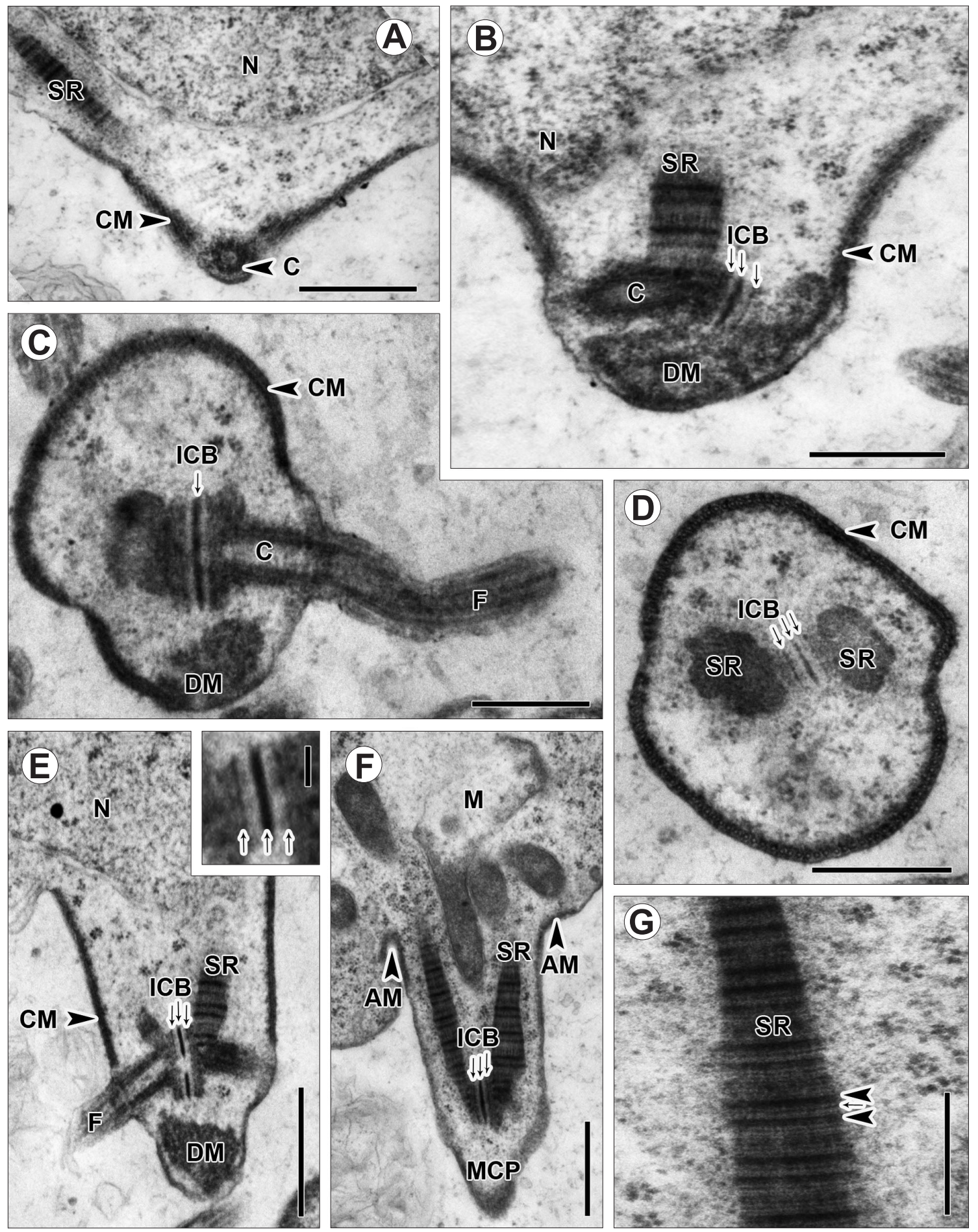

Fig. 1. Early and advanced stages of spermiogenesis in Amphilina foliacea. $\mathbf{A}$ - formation of the centriole with striated rootlet in the apical region of the zone of differentiation; $\mathbf{B}$ - a differentiation zone contains two centrioles (only one visible) with striated rootlet, apical electron-dense material, an intercentriolar body and cortical microtubules; $\mathbf{C}$ - centriole giving rise to a flagellum; D - cross-section of the differentiation zone at the level of a basal portion of the intercentriolar body; note a continuous row of cortical microtubules; $\mathbf{E}$ - free flagella undergo a rotation; inset: detail of the intercentriolar body composed of three electron-dense plates delimiting two electron-lucent zones; $\mathbf{F}$ - formation of the median cytoplasmic process in advanced stages of spermiogenesis; note a large mitochondrion extended into the median cytoplasmic process; $\mathbf{G}$ - detail of the striated rootlet. Abbreviations: AM - arching membranes; C - centriole; CM - cortical microtubules; DM - apical electron-dense material; F - flagellum; ICB - intercentriolar body; $\mathrm{M}$ - mitochondrion; MCP - median cytoplasmic process; $\mathrm{N}$ - nucleus; SR - striated rootlet. [Small arrow - electron-dense plate of the intercentriolar body.] Scale bars: $A=0.7 \mu \mathrm{m} ; \mathrm{B}-\mathrm{D}, \mathrm{G}=0.5 \mu \mathrm{m} ; \mathrm{E}, \mathrm{F}=1 \mu \mathrm{m}$; inset of $\mathrm{E}=0.2 \mu \mathrm{m}$. 

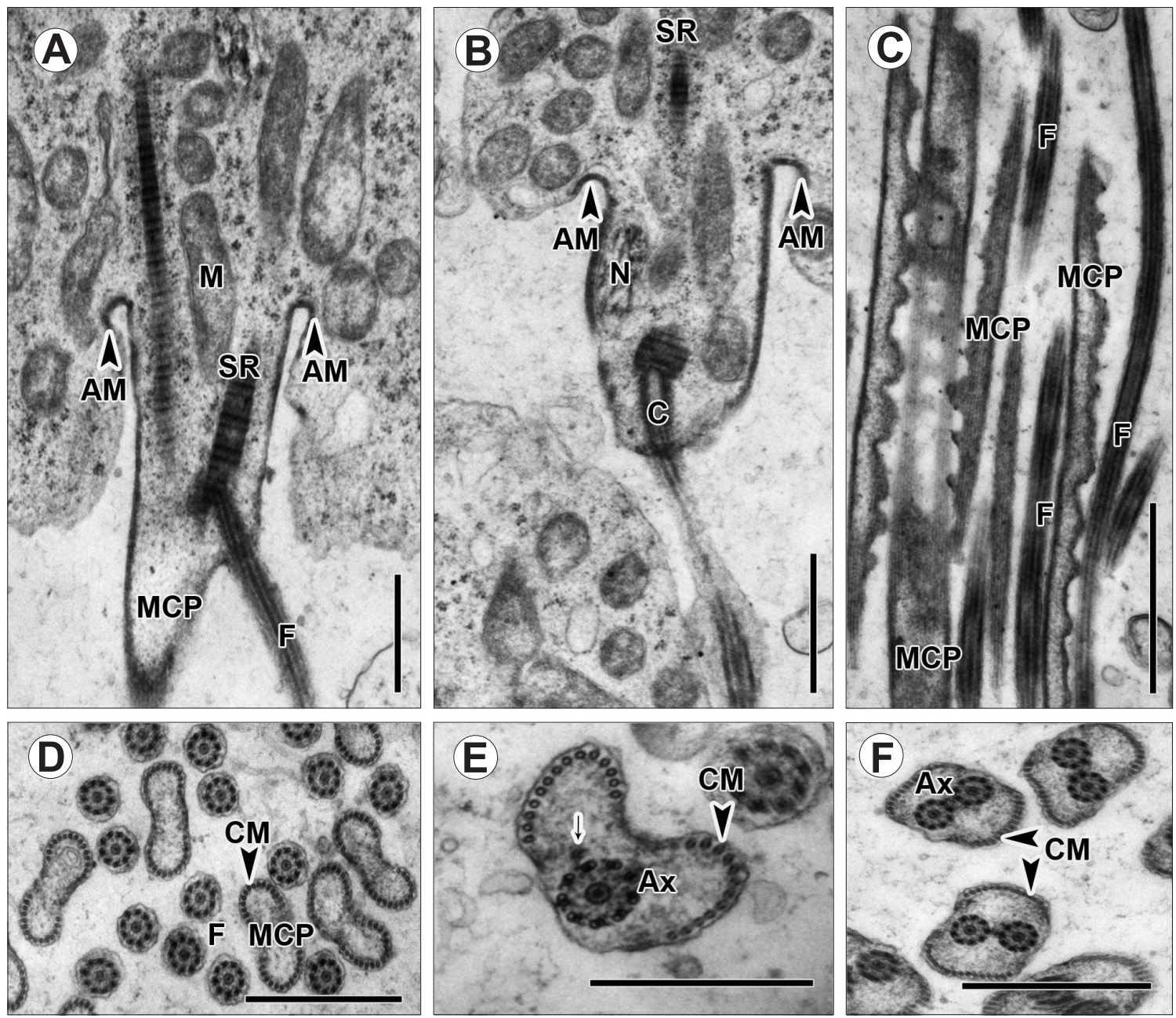

Fig. 2. Advanced stages of spermiogenesis in Amphilina foliacea. A - longitudinal section through the spermatid showing the migration of the mitochondrion towards the median cytoplasmic process at the level of the arching membranes; $\mathbf{B}$ - longitudinal section of the differentiation zone in the advanced stages of spermiogenesis; the centriole and the striated rootlet have a parallel central axis; the nucleus migrates towards the base of the striated rootlet; $\mathbf{C}$ - longitudinal section of the median cytoplasmic process (MCP) and a free flagellum before the fusion of the flagella with the MCP; D - cross-section through the MCP and free flagellum; peripheral microtubules line the lateral sides of the MCP; free flagellum is of the $9+$ " 1 " type; $\mathbf{E}$ - cross-section through the MCP after its fusion with a free flagellum; scattered patches of electron-dense material (small arrow) are present; $\mathbf{F}$ - cross-section through two axonemes incorporated into the MCP. Abbreviations: AM - arching membranes; Ax - axoneme; $\mathrm{C}$ - centriole; $\mathrm{CM}$ - peripheral microtubules; F - flagellum; $\mathrm{M}$ - mitochondrion; $\mathrm{MCP}$ - median cytoplasmic process; $\mathrm{N}$ - nucleus; $\mathrm{SR}$ - striated rootlet. Scale bars: $\mathrm{A}, \mathrm{B}, \mathrm{D}, \mathrm{F}=1 \mu \mathrm{m} ; \mathrm{C}=2 \mu \mathrm{m} ; \mathrm{E}=0.5 \mu \mathrm{m}$.

posed of three electron-dense plates with two electronlucent zones in-between (Figs. 1B, C, 4B). The central electron-dense plate is more distinct and thicker than the two lateral electron-dense components (Fig. 1B, D-F). At the early stages of spermiogenesis, there is an electrondense material in the apical region of the differentiation zone (Figs. 1B, C, 4B-D). The differentiation zone is lined with cortical microtubules arranged under the cell membrane of the spermatid (Figs. 1A-C, 4A-C). In crosssections, cortical microtubules form a ring at the periphery of the differentiation zone (Fig. 1D).

Each of the two centrioles gives rise to a flagellum, which grows outwards (Figs. 1C, 4C). While a median cytoplasmic process develops, the flagella undergo rotation
(Figs. 1E, 4D). At this stage, a ring of arching membrane is formed at the base of the differentiation zone (Fig. 1F). Each of the centrioles is associated with a pyramidal striated rootlet, which is initially orientated perpendicularly to the longitudinal axis of the centriole (Figs. 1E, 4B). Early during this process, the striated rootlet measures about $0.7 \mu \mathrm{m}$ (Fig. 1E), but it grows in size up to $3.5 \mu \mathrm{m}$ during the later stages of development (Fig. 2A). The rootlet has a transverse striation composed of thick $(\sim 20 \mathrm{~nm})$ and very thin electron-dense plates located in a moderately electron-dense matrix. Two distinct electron-dense plates and an interposed thin electron-dense plate are regularly arranged in pairs with an interstrial distance of $30 \mathrm{~nm}$. The distance between two neighbouring pairs of electron- 

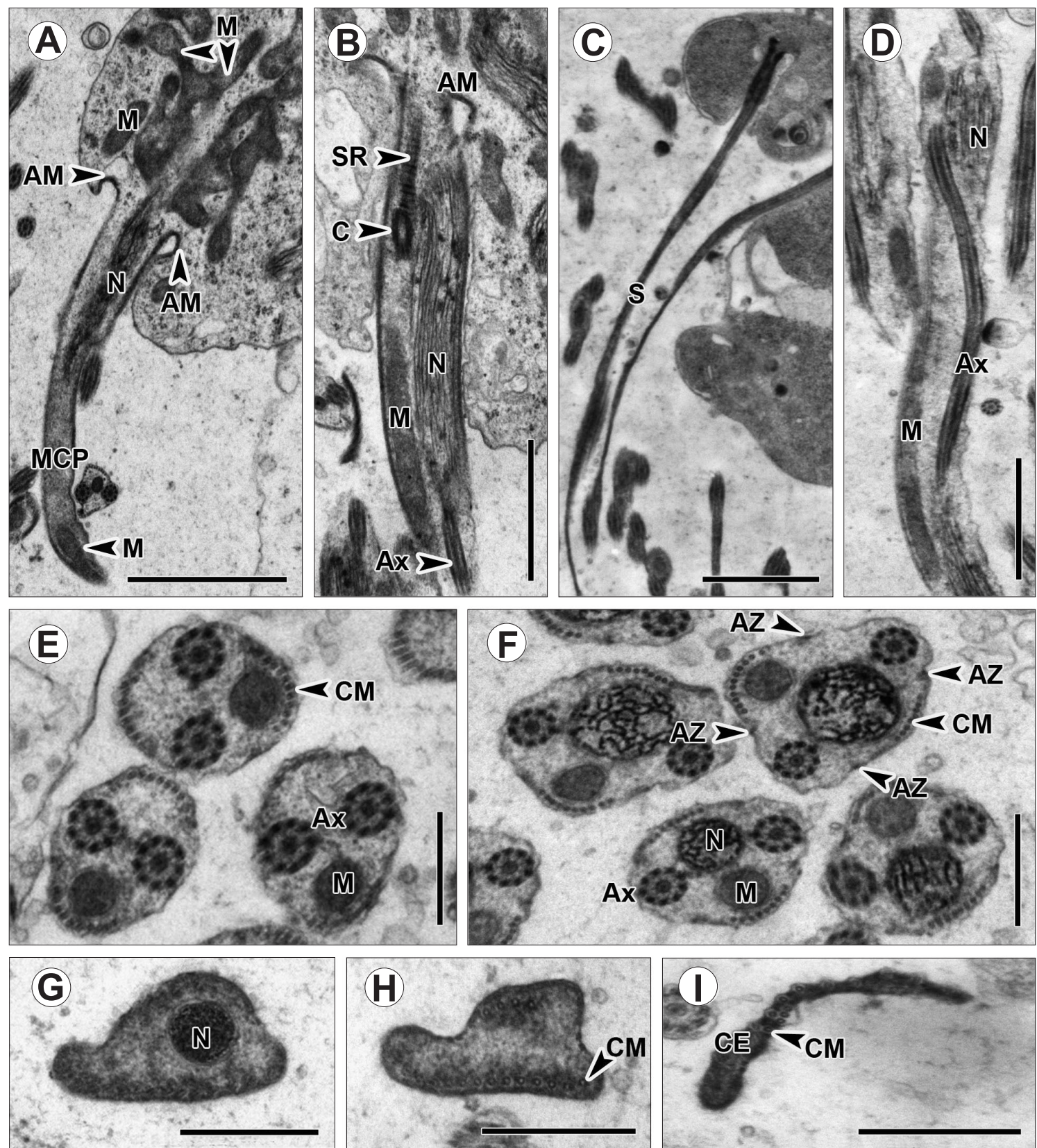

Fig. 3. Advanced and final stages of spermiogenesis in Amphilina foliacea. A - longitudinal section through the well-developed median cytoplasmic process during the migration of the mitochondrion and nucleus; note evident fusion of several mitochondria in the region below the arching membranes; $\mathbf{B}$ - longitudinal section showing the centriole with a striated rootlet, mitochondrion and nucleus in a late spermatid at the end of spermiogenesis; $\mathbf{C}$ - late spermatid pinched off from the residual cytoplasm at the final stage of spermiogenesis; D - longitudinal section through a late spermatid; $\mathbf{E}$ - cross-section through a late spermatid containing two axonemes, a mitochondrion and cortical microtubules; $\mathbf{F}$ - cross-section through the nucleated region of a late spermatid; $\mathbf{G}$ - posterior part of the late spermatid containing the reduced profile of a nucleus; $\mathbf{H}$ - posterior part of the late spermatids more distally, with the nucleus absent; I - terminal cytoplasmic expansion corresponding to the posterior extremity of the late spermatids, which occur in the testicular lumen. Abbreviations: AM - arching membranes; Ax - axoneme; AZ - attachment zones; C - centriole; $\mathrm{CE}$ - cytoplasmic expansion; $\mathrm{CM}$ - cortical microtubules; $\mathrm{M}$ - mitochondrion; $\mathrm{MCP}$ - median cytoplasmic process; $\mathrm{N}$ - nucleus; $\mathrm{S}-$ spermatid; $\mathrm{SR}-$ striated rootlet. Scale bars: $\mathrm{A}-\mathrm{D}=2 \mu \mathrm{m} ; \mathrm{E}-\mathrm{I}=0.5 \mu \mathrm{m}$.

dense plates is $\sim 120 \mathrm{~nm}$. A periodic unit of the striated rootlet measures $220 \mathrm{~nm}$ (Fig. 1F, G).

Both flagella grow and rotate towards the median cytoplasmic process (Figs. 2A, 4D, E). The arching mem- brane lines the proximal extremity of the differentiation zone (Figs. 1F, 2A, 3A, C). It consists of a double membrane located beneath the cell membrane of the spermatid. During flagellar rotation, an enlarged mitochondrion 
A

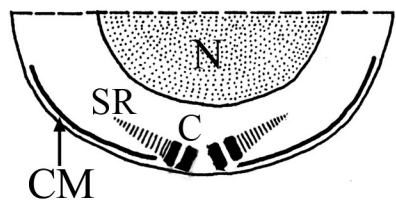

B

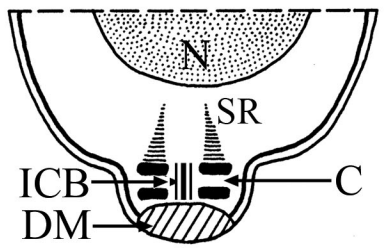

E

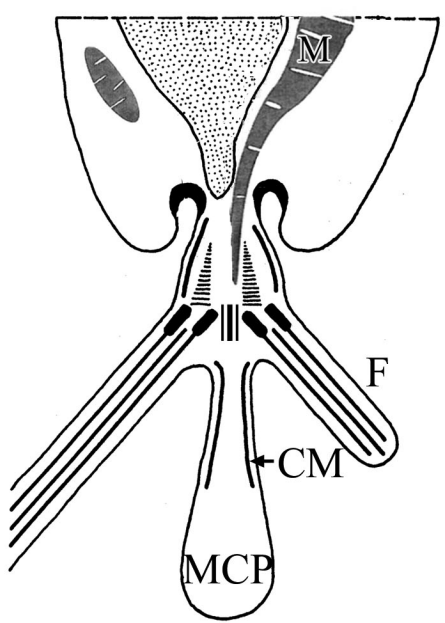

C

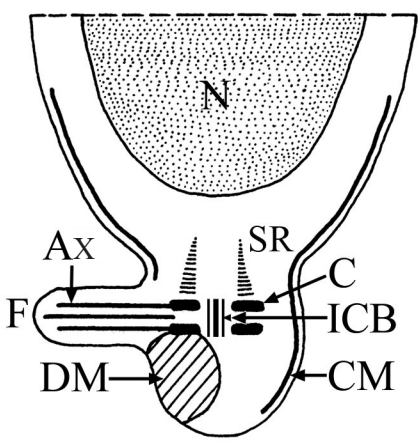

$\mathbf{F}$

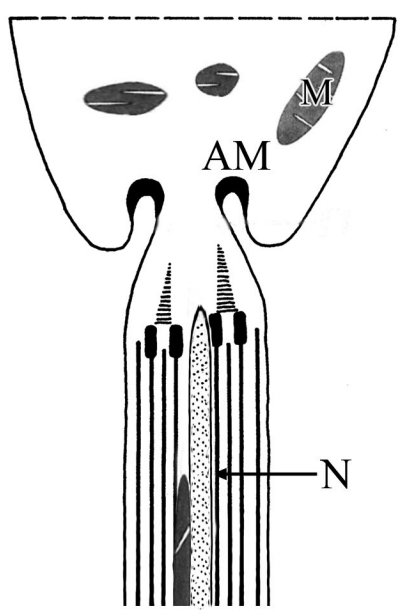

D

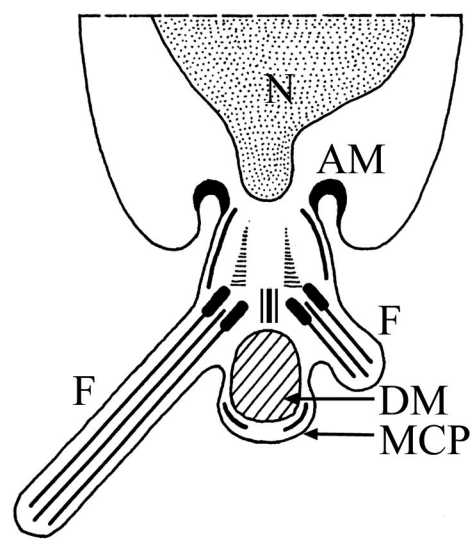

G

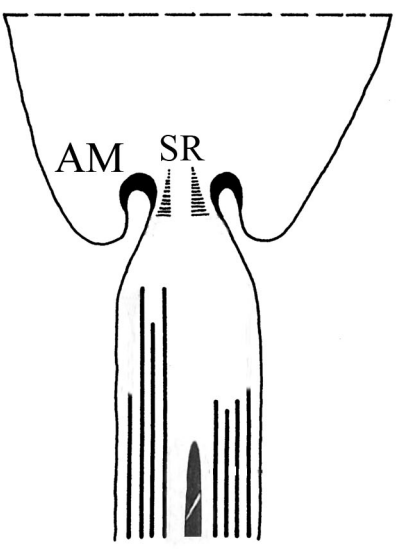

Fig. 4. Schematic reconstruction of the main stages of spermiogenesis in Amphilina foliacea. $\mathbf{A}-\mathbf{D}$ - the early stages; $\mathbf{E}$ - the advanced stage; F, G - the final stages. Abbreviations: AM - arching membranes; Ax - axoneme; C - centriole; $\mathrm{CM}$ - cortical microtubules; DM - dense material; F - flagellum; ICB - intercentriolar body; M - mitochondrion; $\mathrm{MCP}$ - median cytoplasmic process; $\mathrm{N}$ - nucleus; SR - striated rootlet.

is directed towards the striated rootlets (Figs. 2A, 4E). When the centriole of one of the two flagella becomes oriented parallel to the median cytoplasmic process, the nucleus follows the mitochondrion into the cytoplasmic process (Fig. 2B). Longitudinal and cross-sections reveal a swollen median cytoplasmic process and a continuous row of cortical microtubules at this stage of spermiogenesis (Fig. 2C, D). Free flagella approach the median cytoplasmic process prior to fusing with its surface.

Cross-sections showing one (Fig. 2E) or two (Fig. 2F) incorporated flagella indicate an unequal length of the two free flagella, which grow during spermiogenesis. After the proximodistal fusion has started, the mitochondrion migrates toward the median cytoplasmic process, followed by the now elongated nucleus (Figs. 3A, 4F). Shortly before the migration of the nucleus into the median cytoplasmic process has finished, the diameter of the zone of differentiation decreases and the striated rootlet associated with the basal body can only be observed occasionally in the spermatid body (Fig. 3B). At the end of spermiogenesis, spermatids are pinched off from the residual cytoplasm ('residual body') at the level of the arching membranes (Figs. 3C, 4G).

Longitudinal and cross-sections through the late spermatids show that the incorporated axoneme exhibits a typical $9+$ "1" structure (Fig. 3D-F). Two opposite rows of cortical microtubules line the periphery of the late spermatid in the region of the mitochondrion (Fig. 3E) and electron-lucent nucleus (Fig. 3F). Four small electron-dense plaques, indicating the attachment zones where the axonemes were incorporated into the sperm body during spermiogenesis, are located beneath the plasma membrane (Fig. 3F). Cross-sections through the distal part of the spermatid show the nucleated and anucleated regions (Fig. 3G, H). The posterior extremity of the late spermatid is represented by a narrow cytoplasmic extension lined by up to 11 cortical microtubules (Fig. 3I). 


\section{DISCUSSION}

Spermiogenesis in Amphilina foliacea follows the basic pattern described for other members of the Amphilinidea (see Rohde and Watson 1986, Xylander 1986). It includes the presence of two centrioles with typical striated rootlets in the zone of differentiation, the formation and rotation of two free flagella, a proximodistal fusion, and the migration of a mitochondrion and nucleus into the spermatid body. In addition, the present study has revealed, for the first time, the occurrence of: (1) apical electron-dense material in the early stages of spermiogenesis; (2) an intercentriolar body; and (3) significant ultrastructural differences in the distal part of spermatozoa from the testicular cavity and those from the sperm ducts of $A$. foliacea.

To date, apical electron-dense material has not been reported either in the Amphilinidea or the Gyrocotylidea (see Xylander 1986, 1989). This remarkable character has been found in some other tapeworms, e.g. caryophyllideans (Bruňanská and Poddubnaya 2006, Gamil 2008, Miquel et al. 2008, Bruňanská 2009, 2010, Yoneva et al. 2011, 2012a, b, Bruňanská and Kostič 2012), spathebothriideans (Bruňanská et al. 2006, Bruňanská and Poddubnaya 2010), bothriocephalideans (Bruňanská et al. 2001, Levron et al. 2005, 2006a, Śípková et al. 2010, 2011, Marigo et al. 2012a), diphyllobothriideans (Levron et al. 2006b, 2009a, 2013) and proteocephalideans (Marigo et al. 2012b). Apical electron-dense material has never been reported during spermiogenesis in the Digenea or Monogenea.

The intercentriolar body was not described in the previous study of $A$. foliacea by Xylander (1986, 1993) and, consequently, this structure was considered incorrectly to have been lost secondarily in amphilinideans (Watson and Rohde 1995). The present paper shows that the intercentriolar body is present during spermiogenesis of $A$. foliacea and consists of three electron-dense plates delimited by two electron-lucent zones. Intercentriolar bodies of similar structure have been described in some caryophyllideans (Miquel et al. 2008, Bruňanská 2009, 2010, Yoneva et al. 2011, 2012a, b, Bruňanská and Kostič 2012), spathebothriideans (Bruňanská et al. 2006, Bruňanská and Poddubnaya 2010), bothriocephalideans (Levron et al. 2005, 2006a, Śípková et al. 2010, 2011, Marigo et al. 2012a) and mesocestoidid 'cyclophyllideans' (Miquel et al. 2007). A more developed intercentriolar body composed of up to five electron-dense plates has been reported in the amphilinidean Austramphilina elongata (by Rohde and Watson 1986), and diphyllobothriideans (Levron et al. 2006b, 2009a, 2013). Six electron-dense plates from an intercentriolar body have been reported in the Aspidogastrea (Levron et al. 2009b), whereas seven electron-dense layers were found in trypanorhynch cestodes (McKerr 1985), most species of the Digenea (Bakhoum et al. 2012) and polyopisthocoty- lean Monogenea (Quilichini et al. 2009). The latter authors argued that the intercentriolar body is different in the Digenea and polyopisthocotylean Monogenea. Intercentriolar bodies are considered to be absent during spermiogenesis in the Monopisthocotylea (Justine 1998). This indicates a gradual reduction of the intercentriolar body in the Neodermata.

A mitochondrion is an important component of the spermatozoon in parasitic Platyhelminthes. It occurs in the spermatozoa of most members of the Neodermata studied, but is absent in the Eucestoda - its absence is thus an autapomorphy of this group (Xylander 1989, 2001, Justine 1998). Numerous mitochondria have been described in the zone of differentiation during spermiogenesis in amphilinideans (Xylander 1986, Rohde and Watson 1986). The present study illustrates, however, that several small mitochondria may fuse to form a single large mitochondrion, which migrates into the median cytoplasmic process, as shown by Burton (1972) for the Digenea. In contradiction to the statement that the mitochondria migrate into the cytoplasmic process after the nucleus in most digeneans (Burton 1972) and in some amphilinideans (Rohde and Watson 1986), we observed a prenuclear migration of the mitochondrion in A. foliacea. This type of mitochondrial migration has also been described in some digeneans (Cifrian et al.1993, Gracenea et al. 1997, Bakhoum et al. 2011).

In the present study, the distal part of the spermatid of A. foliacea is shown to exhibit ultrastructural differences compared to the mature spermatozoon from sperm ducts or the seminal receptacle (Xylander 1986, Bruňanská et al. 2012). Gametes from the testes taper at the distal extremity to form a cytoplasmic expansion containing the nucleus and some cortical microtubules. To date, a similar tapering of the spermatozoon has not been described for the Amphilinidea. It is present in the proximal end of the spermatozoon of the monocotylid monogenean Troglocephalus rhinobatidis Young, 1967, in a progenetic trematode Bucephaloides gracilescens (Rudolphi, 1819) (now Prosorhynchoides borealis) and in the distal extremity of male gametes from testes of the spathebothriidean tapeworm Cyathocephalus truncatus (Pallas, 1781) (Watson 1997, Erwin and Halton 1983, Bruňanská et al. 2006). It should be noted that, in the latter studies on the monocotylid and the trematode, the proximal region of the spermatozoon corresponds to the post-nuclear region. Thus, it is identical with the distal region of the spermatozoon of $A$. foliacea since the nucleus marks the distal part of the spermatozoon in the Digenea, Monogenea (Justine and Mattei 1982, 1983) and Cestoda (Bâ et al. 1991).

On the other hand, the distal region of the spermatozoa of $A$. foliacea from the sperm ducts and the seminal receptacle contains only the nucleus and no cytoplasmic expansions were observed (Bruňanská et al. 2012). This 
region thus resembles the spermatozoon of the spathebothriidean C. truncatus (see Bruňanská et al. 2006). Moreover, the nucleus also occurs more frequently in the posterior extremity of mature digenean spermatozoa (see Levron et al. 2004).

Finally, we can conclude that $A$. foliacea shares some characteristics of spermiogenesis with both the digeneans and some of the 'lower' cestodes (e.g. the presence of an intercentriolar body and the ultrastructure of the posterior extremity of both the spermatid and the mature spermatozoon). Migration of the mitochondrion into the developing spermatid during spermiogenesis in the Amphilinidea, Gyrocotylidea, Monogenea and Trematoda, but not in the Eucestoda, shows that this pattern belongs to the underlying pattern of the Neodermata. In addition, the pattern of spermiogenesis in A. foliacea indicates a sister group relationships between the Amphilinidea and the Eucestoda, as indicated previously by molecular anal- yses (Waeschenbach et al. 2012) and many morphological and biological characteristics (Xylander 2001).

Acknowledgements. We are grateful to the staff of the Centre of Electron Microscopy, I.D. Papanin Institute for Biology of Inland Waters, Russian Academy of Sciences, Borok, Russia, for technical assistance. We also thank Dr. David I. Gibson, Natural History Museum, London, for corrections of an early version of the manuscript. This study was supported by the Russian Foundation for Fundamental Research (project no. 12-04-00149-a to LGP), and the Grant Agency of the Slovak Republic VEGA (project no. 2/0047/11 to MB). This research was undertaken within the framework of a joint research project supported by a bilateral agreement on scientific exchange and cooperation between the Russian and Slovak Academies of Sciences, and the Centre of Excellence for Parasitology (Code ITMS: 26220120022) based on the support of the Operational Programme 'Research \& Development' funded by the European Regional Development Fund (rate 0.1).

\section{REFERENCES}

BÂ C.T., Marchand B., Mattei X. 1991: Demonstration of the orientation of cestode spermatozoon illustrated by the ultrastructural study of spermiogenesis and the spermatozoon of a Cyclophyllidea: Thysaniezia ovilla Rivolta, 1874. J. Submicrosc. Cytol. Pathol. 23: 605-612.

Bakhoum A.J.S., Bâ C.T., Shimalov V.V., Torres J., Miquel J. 2011: Spermatological characters of the digenean Rubenstrema exasperatum (Rudolphi, 1819) (Plagiorchioidea, Omphalometridae). Parasitol. Res. 108: 1283-1293.

Bakhoum A.J.S., Feliu C., BÂ C.T., Miquel J. 2012: Spermiogenesis and spermatozoon of the liver fluke Mediogonimus jourdanei (Microphalloidea: Prosthogonimidae), a parasite of Myodes glareolus (Rodentia: Cricetidae). Folia Parasitol. 59: $32-42$.

Bazitov A., Lyapkalo A., Yukhimenko S. 1979: Spermatogenesis of Amphilina japonica (Goto et Ishii, 1936) (Amphilinidea). Vestnik Zoologi, Kiev 1: 50-55. (In Russian.)

BRUŇANSKÁ M. 2009: Spermatological characters of the caryophyllidean cestode Khawia sinensis Hsü, 1935, a carp parasite. Parasitol. Res. 105: 1603-1610.

BRUŇANSKÁ M. 2010: Recent insights into spermatozoa development and ultrastructure in the Eucestoda. In: T. Lejeune and P. Delvaux (Eds.), Human Spermatozoa: Maturation, Capacitation and Abnormalities. Nova Science Publishers, Inc., New York, pp. 327-354.

BRUŇAnSKÁ M., Kostič B. 2012: Revisiting caryophyllidean type of spermiogenesis in the Eucestoda based on spermatozoon differentiation and ultrastructure of Caryophyllaeus laticeps (Pallas, 1781). Parasitol. Res. 110: 141-149.

Bruñanská M., Nebesář́ová J., Scholz T., Fagerholm H.-P. 2001: Spermiogenesis in the pseudophyllid cestode Eubothrium crassum (Bloch, 1779). Parasitol. Res. 87: 579-588.

Bruñanská M., Poddubnaya L.G. 2006: Spermiogenesis in the caryophyllidean cestode Khawia armeniaca (Cholodkovski, 1915). Parasitol. Res. 99: 449-454.

Bruñanská M., Poddubnaya L.G. 2010: Spermatological characters of the spathebothriidean tapeworm Didymobothrium rudolphii (Monticelli, 1890). Parasitol. Res. 106: 1435-1442.
Bruñanská M., Poddubnaya L.G., Xylander W.E.R. 2012: Spermatozoon cytoarchitecture of Amphilina foliacea (Platyhelminthes, Amphilinidea). Parasitol. Res. 111: 2063-2069.

Bruñanská M., Scholz T., Dezfuli B., Poddubnaya L.G. 2006: Spermiogenesis and sperm ultrastructure of Cyathocephalus truncatus (Pallas, 1781) Kessler, 1868 (Cestoda: Spathebothriidea). J. Parasitol. 92: 884-892.

BURTON P.R. 1972: Fine structure of the reproductive system of a frog lung-fluke. III. The spermatozoon and its differentiation. J. Parasitol. 58: 68-83.

Cifrian B., Garcia-Corrales P., Martinez-Alos S. 1993: Ultrastructural study of the spermatogenesis and mature spermatozoon of Dicrocoelium dendriticum (Plathelminthes, Digenea). Parasitol. Res. 79: 204-212.

ERwin B.E., Halton D.W. 1983: Fine structural observations on spermatogenesis in a progenetic trematode, Bucephaloides gracilescens. Int. J. Parasitol. 13: 413-426.

Euzet L., Świderski Z., Mokhtar-Maamouri F. 1981: Ultrastructure comparée du spermatozoïde des cestodes. Relations avec la phylogénèse. Ann. Parasitol. Hum. Comp. 56: 247-259.

GAMIL I.S. 2008: Ultrastructural studies of the spermatogenesis and spermiogenesis of the caryophyllidean cestode Wenyonia virilis (Woodland, 1923). Parasitol. Res. 103: 777-785.

Gracenea M., Ferrer J.R., González-Moreno O., Trullols M. 1997: Ultrastructural study of spermatogenesis and spermatozoon in Postorchigenes gymnesicus (Trematoda, Lecithodendriidae). J. Morphol. 234: 223-232.

Hoberg E.P., Mariaux J., Brooks D.R. 2001: Phylogeny among the orders of the Eucestoda (Cercomeromorphae): integrating morphology, molecules and total evidence. In: D.T.J. Littlewood and R.A. Bray (Eds.), Interrelationships of the Platyhelminthes. Taylor and Francis, London and New York, pp. 112-126.

Justine J.-L. 1998: Spermatozoa as phylogenetic characters for the Eucestoda. J. Parasitol. 84: 385-408.

Justine J.-L. 2001: Spermatozoa as phylogenetic characters for the Platyhelminthes. In: D.T.J. Littlewood and R.A. Bray (Eds.), 
Interrelationships of the Platyhelminthes. Taylor and Francis, London and New York, pp. 231-238.

Justine J.-L. 2003: Ultrastructure des spermatozoïdes et phylogénie des Neodermata. In: C. Combes and J. Jourdane (Eds.), Taxonomy, Ecology and Evolution of Metazoan Parasites. PUP, Perpignan, pp. 359-380.

Justine J.-L., Mattei X. 1982: Réinvestigation de l'ultrastructure du spermatozoïde d'Haematoloechus (Trematoda: Haematoloechidae). J. Ultrastruct. Res. 81: 322-332.

Justine J.-L., Mattei X. 1983: Comparative ultrastructural study of spermiogenesis in monogeneans (flatworms). J. Ultrastruct. Res. 84: 213-223.

Levron C., Bruñanská M., Marchand B. 2005: Spermiogenesis and sperm ultrastructure of the pseudophyllidean cestode Triaenophorus nodulosus (Pallas, 1781). Parasitol. Res. 98: 26-33.

Levron C., Bruñanská M., Poddubnaya L.G. 2006a: Spermatological characters of the pseudophyllidean cestode Bothriocephalus scorpii (Müller, 1776). Parasitol. Int. 55: 113-120.

Levron C., Bruñanská M., Poddubnaya L.G. 2006b: Spermatological characters in Diphyllobothrium latum (Cestoda, Pseudophyllidea). J. Morphol. 267: 1110-1119.

Levron C., Miquel J., Oros M., Scholz T. 2010: Spermatozoa of tapeworms (Platyhelminthes, Eucestoda): advances in ultrastructural and phylogenetic studies. Biol. Rev. 85: 523-543.

Levron C., Sitko J., Scholz T. 2009a: Spermiogenesis and spermatozoon of the tapeworm Ligula intestinalis (Diphyllobothriidae): phylogenetic implications. J. Parasitol. 95: 1-9.

Levron C., Suchanová E., Poddubnaya L., Oros M., Scholz T. 2009b: Spermatological characters of the aspidogastrean Aspidogaster limacoides Diesing, 1835. Parasitol. Res. 105: 77-85.

Levron C., Ternengo S., Marchand B. 2004: Ultrastructure of spermiogenesis and the spermatozoon of Monorchis parvus Looss, 1902 (Digenea, Monorchiidae), a parasite of Diplodus annularis (Pisces, Teleostei). Parasitol. Res. 93: 102-110.

Levron C., Yoneva A., Kalbe M. 2013: Spermatological characters in the diphyllobothriidean Schistocephalus solidus (Cestoda). Acta Zool. (Stockh.): in press. DOI: 10.1111/j.14636395.2011.00549.x

Marigo A.M., Delgado E., Torres J., Bâ C.T., Miquel J. 2012a: Spermiogenesis and spermatozoon ultrastructure of the bothriocephalidean cestode Clestobothrium crassiceps (Rudolphi, 1819), a parasite of the teleost fish Merluccius merluccius (Gadiformes: Merlucciidae). Parasitol. Res. 110: 19-30.

Marigo A.M., Levron C., BÂ C.T., Miquel J. 2012b: Ultrastructural study of spermiogenesis and the spermatozoon of the proteocephalidean cestode Barsonella lafoni de Chambrier et al., 2009, a parasite of the catfish Clarias gariepinus (Burchell, 1822) (Siluriformes, Clariidae). Zool. Anz. 251: 147-159.

McKerR G. 1985: The fine structure and physiology of a trypanorhynch tapeworm Grillotia erinaceus. PhD thesis, The Queen's University of Belfast, Belfast, $205 \mathrm{pp}$.

Miquel J., Eira C., Świderski Z., Conn D.B. 2007: Mesocestoides lineatus (Goeze, 1782) (Mesocestoididae): new data on sperm ultrastructure. J. Parasitol. 93: 545-552.

Miquel J., Świderski Z., Mackiewicz J.S., Ibraheem M.H. 2008: Ultrastructure of spermiogenesis in the caryophyllidean cestode Wenyonia virilis Woodland, 1923, with re-assessment of flagellar rotation in Glaridacris catostomi Cooper, 1920. Acta Parasitol. 53: 19-29.

Quilichini Y., Foata J., Marchand B. 2009: Ultrastructural study of spermiogenesis and the spermatozoon of Microcotyle

Received 19 July 2012 pancerii (Monogenea: Polyopisthocotylea: Microcotylidae), a parasite of meagre Argyrosomus regius (Pisces: Teleostei). J. Parasitol. 95: 261-270.

RohDE K., WATSON N. 1986: Ultrastructure of spermatogenesis and sperm of Austramphilina elongata (Platyhelminthes, Amphilinidea). J. Submicrosc. Cytol. 18: 361-374.

Š́́pková L., Levron C., Freeman M., Scholz T. 2010: Spermiogenesis and spermatozoon of the tapeworm Parabothriocephalus gracilis (Bothriocephalidea): ultrastructural and cytochemical studies. Acta Parasitol. 55: 58-65.

Š́́ípová L., Levron C., Oros M., Justine J.-L. 2011: Spermatological characters of bothriocephalideans (Cestoda) inferred from an ultrastructural study on Oncodiscus sauridae and Senga sp. Parasitol. Res. 109: 9-18.

ŚWIDERSKI Z. 1986. Three types of spermiogenesis in cestodes. In: T. Imura, S. Maruse, Z. Suzuki (Eds.) Proc. XIth Int. Congr. Electron Microsc., 31 August-7 September 1986, Kyoto. Kyoto University Press, pp. 2959-2960.

Waeschenbach A., Webster B.L., Littlewood D.T.J. 2012: Adding resolution to ordinal level relationships of tapeworms (Platyhelminthes: Cestoda) with large fragments of mtDNA. Mol. Phylogenet. Evol. 63: 834-847.

WATSON N.A. 1997: Spermiogenesis and sperm ultrastructure in Troglocephalus rhinobatidis, Neoheterocotyle rhinobatidis and Merizocotyle australensis (Platyhelminthes, Monogenea, Monopisthocotylea, Monocotylidae). Int. J. Parasitol. 27: 389_ 401.

Watson N.A., Rohde K. 1995: Re-examination of spermatogenesis of Multicotyle purvisi (Platyhelminthes, Aspidogastrea). Int. J. Parasitol. 25: 579-586.

XYlander W.E.R. 1986: Zur Ultrastruktur und Biologie der Gyrocotylida und Amphilinida und ihre Stellung im System der Plathelminthen. Doctoral thesis, University of Gottingen, $307 \mathrm{pp}$.

XYlander W.E.R. 1989: Ultrastructural studies on the reproductive system of Gyrocotylidea and Amphilinidea (Cestoda): spermatogenesis, spermatozoa, testes and vas deferens of $G y$ rocotyle. Int. J. Parasitol. 19: 897-905.

XYLANDER W.E.R. 1993: Ultrastructural investigations of spermatogenesis and morphology of spermatozoa, vas efferens and receptaculum seminis of Amphilina foliacea (Cestoda, Amphilinidea). Verh. Dtsch. Zool. Ges. 86: 184.

Xylander W.E.R. 2001: The Gyrocotylidea, Amphilinidea and the early evolution of Cestoda. In: D.T.J. Littlewood and R.A. Bray (Eds.), Interrelationships of the Platyhelminthes, Taylor and Francis, London, pp. 103-111.

Yoneva A., Levron C., Ash A., Scholz T. 2012a: Spermatological characters of monozoic tapeworms (Cestoda: Caryophyllidea), including first data on a species from the Indomalayan catfish. J. Parasitol. 98: 423-430.

Yoneva A., Levron C., Oros M., Orosová M., Scholz T. 2011: Ultrastructure of spermiogenesis and mature spermatozoon of Breviscolex orientalis (Cestoda: Caryophyllidea). Parasitol. Res. 108: 997-1005.

Yoneva A., Levron C., Oros M., Orosová M., Scholz T. 2012b: Spermiogenesis and spermatozoon ultrastructure of Hunterella nodulosa (Cestoda: Caryophyllidea), a monozoic parasite of suckers (Catostomidae) in North America. Folia Parasitol. 59: $179-186$.

Accepted 5 October 2012 